\title{
Rarely Reported Cryptobenthic Fish in Marine Caves of the Eastern Mediterranean Sea
}

\author{
Michail Ragkousis ${ }^{1}$ (), Markos Digenis ${ }^{1,2}$, Marcelo Kovačić ${ }^{3}$, , Stelios Katsanevakis ${ }^{1}(\mathbb{D}$ \\ and Vasilis Gerovasileiou ${ }^{2, *}$ (1)
}

1 Department of Marine Sciences, University of the Aegean, University Hill, 81100 Mytilene, Greece; ragkousis.diving@gmail.com (M.R.); markosdigenis@gmail.com (M.D.); stelios@katsanevakis.com (S.K.)

2 Hellenic Centre for Marine Research (HCMR), Institute of Marine Biology, Biotechnology and Aquaculture (IMBBC), P.O. Box 2214, 71003 Heraklion, Greece

3 Natural History Museum Rijeka, Lorenzov Prolaz 1, 51000 Rijeka, Croatia; marcelo@prirodoslovni.com

* Correspondence: vgerovas@hcmr.gr

check for updates

Citation: Ragkousis, M.; Digenis, M.; Kovačić, M.; Katsanevakis, S.; Gerovasileiou, V. Rarely Reported Cryptobenthic Fish in Marine Caves of the Eastern Mediterranean Sea. J. Mar. Sci. Eng. 2021, 9, 557. https:// doi.org/10.3390/jmse9060557

Academic Editor: Francesco Colloca

Received: 5 May 2021

Accepted: 19 May 2021

Published: 21 May 2021

Publisher's Note: MDPI stays neutral with regard to jurisdictional claims in published maps and institutional affiliations.

Copyright: (c) 2021 by the authors. Licensee MDPI, Basel, Switzerland. This article is an open access article distributed under the terms and conditions of the Creative Commons Attribution (CC BY) license (https:// creativecommons.org/licenses/by/ $4.0 /)$.

\begin{abstract}
Data on the distribution and ecology of cryptobenthic fish of marine caves in the Mediterranean Sea are extremely scarce but necessary for scientists and marine managers alike in order to understand these fish's ecological role and assess their conservation status. Broadscale surveys by implementing underwater visual census and photographic sampling in marine caves of the northeastern Mediterranean Sea, within different expeditions during the last 5 years, brought to light new records of eight rarely reported cryptobenthic fish species. To a smaller extent, complementary citizen science data from diving professionals of Crete were used to fill distribution gaps. A total of 36 new records (66 individuals) from 18 marine caves and caverns of the Aegean and northeastern Levantine Seas were assembled, belonging to the gobies Corcyrogobius liechtensteini, Didogobius splechtnai, Gammogobius steinitzi, and Thorogobius ephippiatus, the blenny Microlipophrys nigriceps, the tripterygiid Tripterygion melanurum, the speleophilic bythitid Grammonus ater, and the gobiesocid Lepadogaster cf. lepadogaster. The above species have been rarely reported from the Eastern Mediterranean Sea, with D. splechtnai and G. steinitzi being recorded for the first and second time from Greek waters, respectively, while L. cf. lepadogaster constitutes the second record of a clingfish species in a marine cave of the Aegean Sea. Interesting behavioral and ecological habits were also noted for some species, based on in situ observations and photographic evidence. Our study contributes to filling gaps in the knowledge of cave fish diversity and demonstrates that cryptobenthic mobile species in understudied cryptic habitats are more common than previously thought in the Mediterranean Sea.
\end{abstract}

Keywords: cryptobenthic fish; marine caves; cryptic habitats; mobile species; visual census; Pisces; Gobiidae; Blenniidae; Tripterygiidae; Bythitidae; Gobiesocidae

\section{Introduction}

Mediterranean marine caves have been characterized as "biodiversity reservoirs" harboring rich biodiversity and several protected and rare species [1]. Sadly, though, coastal marine caves, like most coastal habitats, are subjected to major anthropogenic stressors [2,3]. Only a few studies (ca. 40) investigate ichthyofauna in this unique ecosystem, with 112 species reported so far in Mediterranean marine caves [3]. The disproportionate majority of the available data concerns the central and northwestern Mediterranean Sea, with data concerning the eastern Mediterranean limited at best [4].

Cryptobenthic fish are among the less-studied components of Mediterranean ichthyofauna, to the extent that their respective characteristics are mostly unknown [5-7]. Cryptobenthic fish are defined as those having a "small body size that permits the exploitation of restricted habitats, where food and shelter are obtained in or in relation to conditions of substrate complexity and/or restricted living space, with a physical barrier likely to 
be interposed between the small fish and sympatric predators" [8]. Depczynski and Bellwood [9] clarified that this term refers to fish with an adult size typically less than $5 \mathrm{~cm}$ with cryptic behavior, maintaining a close association with benthos. The scarcity of knowledge on cryptobenthic fish is especially relevant for stenotopic cryptobenthic species of understudied cryptic habitats such as marine caves [6,10-13].

Many cryptobenthic fish species were considered rare and until recently were known from very few reports in certain small areas, though that notion is changing [5,12]. Since 2010, efforts have been made to study cryptobenthic fish, particularly gobiids, that have expanded their known distribution $[7,12,14,15]$. Acknowledging the importance of published distributional and ecological data, not only for gaining ecological insights but also as a prerequisite for conservation planning, we report on eight cryptobenthic fish found in numerous marine caves of the northeastern Mediterranean Sea, including new records from Greek waters and the regional marine cave fauna.

\section{Materials and Methods}

The rocky coasts of the Aegean Sea (eastern Mediterranean Sea) host more than 600 marine caves, most of which are located in the island-dominated southern section [16]. Nevertheless, the biodiversity of only a small number of marine caves has been investigated [16]. During the summer months of 2016-2020, in the framework of the MARISCA and ALAS projects [17], we performed underwater visual surveys and photographic sampling in 16 marine caves spanning across the Aegean Sea and the northwestern section of the Levantine Sea. Two scientific SCUBA divers surveyed each cave for at least $90 \mathrm{~min}$. No destructive sampling methods were applied, and species identification was achieved through the examination of photographic material collected in situ.

In the identification process, we provided the diagnosis that positively identifies the species within the family, i.e., among all confamiliar species occurring in the Mediterranean [18]. The diagnosis is the combination of characters needed for the identification of the taxon, and since the species records were evidenced only by the photographs, the provided diagnoses consisted only of characters that can be checked on the photographs [18]

Some records of Grammonus ater, Thorogobius ephippiatus, and Tripterygion melanurum which are conspicuous due to their characteristic coloration and/or shape were identified visually in situ. In addition, 12 photographic records from two marine caves of Crete, dating back to 2010 and 2018, were acquired from diving professionals within a citizen science approach [19]. Information for each record as well as surveyed caves can be found in Table 1 and Figure 1, respectively.

Table 1. Cryptobenthic fish records from Greece reported in the present study (Lat.: Latitude, Lon.: Longitude, CE: Cave Entrance, SD: Semi-Dark zone, DZ: Dark Zone, Obs. type: Observation type, Vis.: Visual observation, Phot.: Photograph, CS.: Citizen Science).

\begin{tabular}{|c|c|c|c|c|c|c|c|c|c|c|}
\hline $\begin{array}{l}\text { ID } \\
\text { No. }\end{array}$ & Species & $\begin{array}{l}\text { No. of } \\
\text { Ind/s }\end{array}$ & Marine Cave & Location & Lat. & Lon. & Zone & $\begin{array}{l}\text { Depth } \\
\text { (m) }\end{array}$ & Year & Obs. Type \\
\hline 1 & $\begin{array}{l}\text { Corcyrogobius } \\
\text { liechtensteini }\end{array}$ & 4 & $\begin{array}{c}\text { Pantieronissi } \\
\text { cave }\end{array}$ & Paros & 36.969 & 25.121 & SD & 10 & 2020 & Phot. \\
\hline 2 & $\begin{array}{l}\text { Didogobius } \\
\text { splechtnai }\end{array}$ & 3 & Nereid cave & N. Crete & 35.552 & 24.064 & $\mathrm{CE}$ & 23 & 2010 & Phot. CS. \\
\hline 3 & $\begin{array}{l}\text { Didogobius } \\
\text { splechtnai }\end{array}$ & 2 & $\begin{array}{c}\text { Agios } \\
\text { Efstathios } \\
\text { cave }\end{array}$ & Milos & 36.774 & 24.581 & $\mathrm{SD}, \mathrm{DZ}$ & 3 & 2020 & Phot. \\
\hline 4 & $\begin{array}{l}\text { Didogobius } \\
\text { splechtnai }\end{array}$ & 1 & $\begin{array}{l}\text { Polyaigos } \\
\text { cave }\end{array}$ & Milos & 36.786 & 24.637 & SD & 5 & 2020 & Phot. \\
\hline 5 & $\begin{array}{c}\text { Gammogobius } \\
\text { steinitzi }\end{array}$ & 2 & Nereid cave & N. Crete & 35.552 & 24.064 & $\mathrm{CE}$ & 23 & 2010 & Phot. CS. \\
\hline 6 & $\begin{array}{c}\text { Gammogobius } \\
\text { steinitzi }\end{array}$ & 1 & $\begin{array}{l}\text { Neptune's } \\
\text { cave }\end{array}$ & Karpathos & 35.556 & 27.21 & SD & 19 & 2020 & Phot. \\
\hline 7 & $\begin{array}{c}\text { Gammogobius } \\
\text { steinitzi }\end{array}$ & 1 & $\begin{array}{l}\text { Kalymnos } \\
\text { cave }\end{array}$ & Kalymnos & 36.926 & 26.972 & SD & 4 & 2020 & Phot. \\
\hline
\end{tabular}


Table 1. Cont.

\begin{tabular}{|c|c|c|c|c|c|c|c|c|c|c|}
\hline $\begin{array}{l}\text { ID } \\
\text { No. }\end{array}$ & Species & $\begin{array}{l}\text { No. of } \\
\text { Ind } / \mathrm{s}\end{array}$ & Marine Cave & Location & Lat. & Lon. & Zone & $\begin{array}{l}\text { Depth } \\
\text { (m) }\end{array}$ & Year & Obs. Type \\
\hline 8 & $\begin{array}{l}\text { Gammogobius } \\
\text { steinitzi }\end{array}$ & 1 & $\begin{array}{l}\text { Polyaigos } \\
\text { cave }\end{array}$ & Milos & 36.786 & 24.637 & SD & 4 & 2020 & Phot. \\
\hline 9 & $\begin{array}{l}\text { Thorogobius } \\
\text { ephippiatus }\end{array}$ & 5 & Nereid cave & N. Crete & 35.552 & 24.064 & $\mathrm{CE}$ & 23 & 2010 & Phot. CS. \\
\hline 10 & $\begin{array}{l}\text { Thorogobius } \\
\text { ephippiatus }\end{array}$ & 1 & Antikeri cave & Amorgos & 36.842 & 25.685 & SD & 15 & 2016 & Vis \\
\hline 11 & $\begin{array}{l}\text { Thorogobius } \\
\text { ephippiatus }\end{array}$ & 1 & Koufonissi-B & $\begin{array}{l}\text { N. Kou- } \\
\text { fonissi }\end{array}$ & 36.948 & 25.621 & SD & 2 & 2016 & Vis \\
\hline 12 & $\begin{array}{l}\text { Thorogobius } \\
\text { ephippiatus }\end{array}$ & 4 & Koufonissi-C & $\begin{array}{l}\text { N. Kou- } \\
\text { fonissi }\end{array}$ & 36.948 & 25.621 & SD & 6 & 2016 & Vis \\
\hline 13 & $\begin{array}{l}\text { Thorogobius } \\
\text { ephippiatus }\end{array}$ & 4 & $\begin{array}{l}\text { Pantieronissi } \\
\text { cave }\end{array}$ & Paros & 36.969 & 25.121 & SD, DZ & 14 & 2016 & Vis \\
\hline 14 & $\begin{array}{l}\text { Thorogobius } \\
\text { ephippiatus }\end{array}$ & 4 & $\begin{array}{l}\text { Pantieronissi } \\
\text { cave }\end{array}$ & Paros & 36.969 & 25.121 & $\mathrm{SD}, \mathrm{DZ}$ & 14 & 2020 & Phot. \\
\hline 15 & $\begin{array}{l}\text { Thorogobius } \\
\text { ephippiatus }\end{array}$ & 1 & $\begin{array}{c}\text { Polyaigos } \\
\text { cave }\end{array}$ & Milos & 36.786 & 24.637 & $\mathrm{DZ}$ & 5 & 2020 & Phot. \\
\hline 16 & $\begin{array}{l}\text { Thorogobius } \\
\text { ephippiatus }\end{array}$ & 2 & Skyros cave & Skyros & 38.818 & 24.487 & $\mathrm{DZ}$ & 4 & 2020 & Vis \\
\hline 17 & $\begin{array}{l}\text { Thorogobius } \\
\text { ephippiatus }\end{array}$ & 2 & Seal's cave & Samos & 37.772 & 27.06 & SD & 2 & 2020 & Vis \\
\hline 18 & $\begin{array}{l}\text { Thorogobius } \\
\text { ephippiatus }\end{array}$ & 1 & $\begin{array}{l}\text { Agios Pavlos } \\
\text { cavern }\end{array}$ & S. Crete & 35.101 & 24.562 & CE & 6 & 2020 & Vis \\
\hline 19 & $\begin{array}{l}\text { Thorogobius } \\
\text { ephippiatus }\end{array}$ & 3 & $\begin{array}{c}\text { Damnoni } \\
\text { cavern }\end{array}$ & S. Crete & 35.17 & 24.409 & SD & 17 & 2020 & Vis \\
\hline 20 & $\begin{array}{l}\text { Microlipophrys } \\
\text { nigriceps }\end{array}$ & 1 & Seal's cave & Rhodes & 36.326 & 28.215 & SD & 11 & 2020 & Phot. \\
\hline 21 & $\begin{array}{l}\text { Tripterygion } \\
\text { melanurum }\end{array}$ & 1 & $\begin{array}{c}\text { Polyaigos } \\
\text { cavern }\end{array}$ & Milos & 36.787 & 24.638 & CE & 4,5 & 2016 & Phot. \\
\hline 22 & $\begin{array}{l}\text { Tripterygion } \\
\text { melanurum }\end{array}$ & 2 & $\begin{array}{c}\text { Kalymnos } \\
\text { cave }\end{array}$ & Kalymnos & 36.926 & 26.972 & SD & 3,5 & 2020 & Phot. \\
\hline 23 & $\begin{array}{l}\text { Tripterygion } \\
\text { melanurum }\end{array}$ & 4 & Seal's cave & Samos & 37.772 & 27.06 & SD & 1 & 2020 & Phot. \\
\hline 24 & $\begin{array}{l}\text { Tripterygion } \\
\text { melanurum }\end{array}$ & 2 & $\begin{array}{c}\text { Agios } \\
\text { Efstathios } \\
\text { cave }\end{array}$ & Milos & 36.774 & 24.581 & SD & 4 & 2020 & Phot. \\
\hline 25 & $\begin{array}{l}\text { Tripterygion } \\
\text { melanurum }\end{array}$ & 2 & Skyros cave & Skyros & 38.818 & 24.487 & CE, SD & 3 & 2020 & Vis \\
\hline 26 & $\begin{array}{l}\text { Tripterygion } \\
\text { melanurum }\end{array}$ & 1 & Vronti cave & Karpathos & 35.537 & 27.213 & SD & 2 & 2020 & Vis \\
\hline 27 & $\begin{array}{l}\text { Tripterygion } \\
\text { melanurum }\end{array}$ & 1 & $\begin{array}{l}\text { Pantieronissi } \\
\text { cave }\end{array}$ & Paros & 36.969 & 25.121 & SD & 5 & 2020 & Vis \\
\hline 28 & $\begin{array}{l}\text { Tripterygion } \\
\text { melanurum }\end{array}$ & 1 & $\begin{array}{l}\text { Polyaigos } \\
\text { cave }\end{array}$ & Milos & 36.786 & 24.637 & $\mathrm{CE}$ & 5 & 2020 & Vis \\
\hline 29 & $\begin{array}{c}\text { Grammonus } \\
\text { ater }\end{array}$ & 1 & Nereid cave & N. Crete & 35.552 & 24.064 & $\mathrm{DZ}$ & 25 & 2010 & Phot. CS. \\
\hline 30 & $\begin{array}{c}\text { Grammonus } \\
\text { ater }\end{array}$ & 1 & Sfakia cave & S. Crete & 35.2 & 24.119 & $\mathrm{DZ}$ & 2 & 2016 & Phot. CS. \\
\hline 31 & $\begin{array}{c}\text { Grammonus } \\
\text { ater }\end{array}$ & 1 & Elephant cave & N. Crete & 35.469 & 24.244 & $\mathrm{DZ}$ & 2 & 2018 & Phot. CS. \\
\hline 32 & $\begin{array}{c}\text { Grammonus } \\
\text { ater }\end{array}$ & 1 & $\begin{array}{l}\text { Pantieronissi } \\
\text { cave }\end{array}$ & Paros & 36.969 & 25.121 & $\mathrm{DZ}$ & 18 & 2020 & Phot. \\
\hline 33 & $\begin{array}{c}\text { Grammonus } \\
\text { ater }\end{array}$ & 1 & $\begin{array}{l}\text { Kalymnos } \\
\text { cave }\end{array}$ & Kalymnos & 36.926 & 26.972 & DZ & 4 & 2020 & Phot. \\
\hline
\end{tabular}


Table 1. Cont.

\begin{tabular}{ccccccccccc}
\hline $\begin{array}{c}\text { ID } \\
\text { No. }\end{array}$ & Species & $\begin{array}{c}\text { No. of } \\
\text { Ind/s }\end{array}$ & Marine Cave & Location & Lat. & Lon. & Zone & $\begin{array}{c}\text { Depth } \\
(\mathbf{m})\end{array}$ & $\begin{array}{c}\text { Year } \\
\text { Obs. Type }\end{array}$ \\
\hline 34 & $\begin{array}{c}\text { Grammonus } \\
\text { ater }\end{array}$ & 1 & $\begin{array}{c}\text { Agios } \\
\text { Efstathios } \\
\text { cave }\end{array}$ & Milos & 36.774 & 24.581 & DZ & 2 & 2020 & Vis. \\
\hline 35 & $\begin{array}{c}\text { Grammonus } \\
\text { ater }\end{array}$ & 1 & $\begin{array}{c}\text { Polyaigos } \\
\text { cave }\end{array}$ & Milos & 36.786 & 24.637 & DZ & 3 & 2020 & Vis. \\
\hline 36 & $\begin{array}{c}\text { Lepadogaster cf. } \\
\text { lepadogaster }\end{array}$ & 1 & $\begin{array}{c}\text { Kalymnos } \\
\text { cave }\end{array}$ & Kalymnos & 36.926 & 26.972 & DZ & 4 & 2020 & Phot. \\
\hline
\end{tabular}

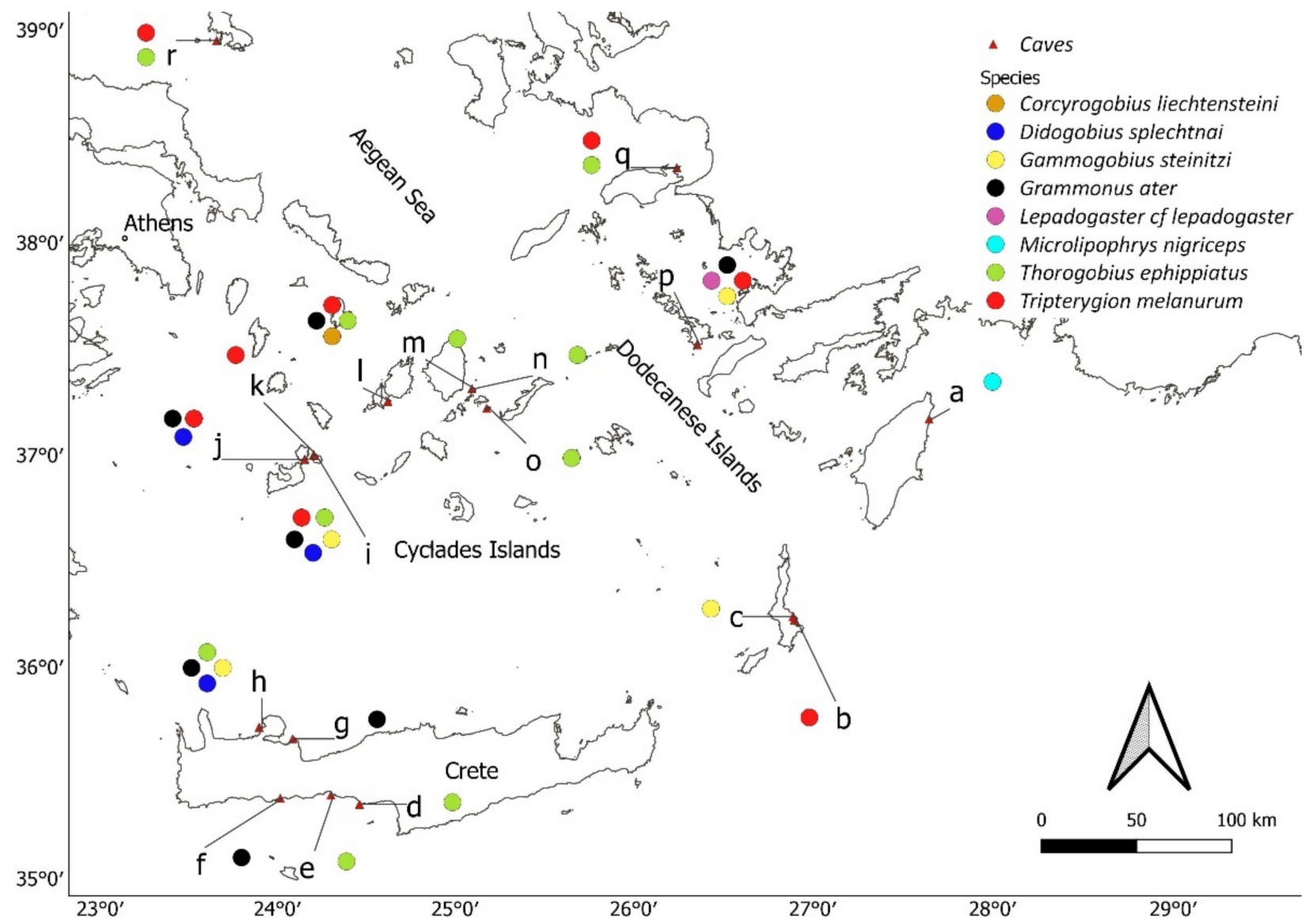

Figure 1. Map of the study area. True cave locations marked with red triangles, with color-coded species occupancy for each location. Letter-coded caves: Seal's cave, Rhodes Island (a); Vronti cave (b); Neptune's cave (c); Agios Pavlos cavern (d); Damnoni cavern (e); Sfakia cave (f); Elephant cave (g); Nereid cave (h), Polyaigos cave (i); Agios Efstathios cave (j); Polyaigos cavern (k); Pantieronissi cave (1); Koufonissi-B (m); Koufonissi-C (n); Antikeri cave (o); Kalymnos cave (p); Seal's cave; Samos Island (q); Skyros cave (r).

\section{Results}

In the studied marine caves, we recorded eight species of rarely reported cryptobenthic fish, namely four species of the family Gobiidae, Corcyrogobius liechtensteini (Kolombatović, 1891), Didogobius splechtnai Ahnelt and Patzner, 1995, Gammogobius steinitzi Bath, 1971, and Thorogobius ephippiatus (Lowe, 1839); Microlipophrys nigriceps (Vinciguerra, 1883) of the family Blenniidae; Tripterygion melanurum (Guichenot, 1850), of the family Tripterygiidae; Grammonus ater (Risso, 1810) of the family Bythitidae; and one representative of the family Gobiesocidae, Lepadogaster cf. lepadogaster (Bonnaterre, 1788). Diagnostic features, 
photographs, morphological, geographical, and ecological data are provided for each species below.

\subsection{Corcyrogobius liechtensteini (Kolombatović, 1891)}

\subsubsection{Diagnosis}

Body with transverse coloration pattern of 10-15 narrow, bluish bars on a reddish-toorangish-brown background; three pale bars extend uninterrupted downwards from the eye over cheek and preopercle continuously to the ventral side (Figure 2) $[20,21]$.

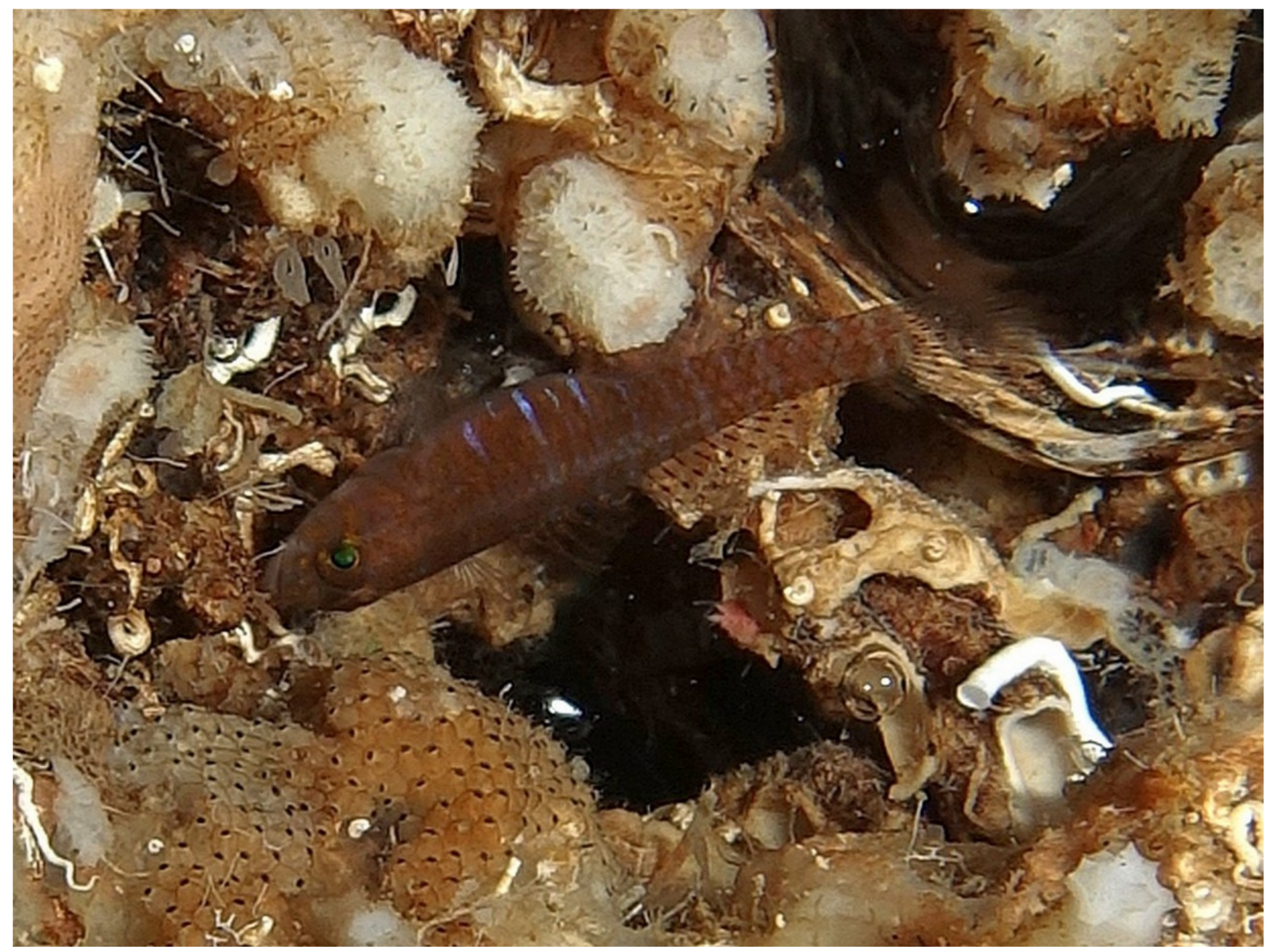

Figure 2. Corcyrogobius liechtensteini photographed in Pantieronissi cave, Cyclades. Photo by M. Ragkousis.

\subsubsection{Morphological, Geographical, and Ecological Data}

Four individuals were photographed in the dark section of Pantieronissi Islet cave, close to Paros Island, approximately $20 \mathrm{~m}$ from the cave's main entrance and $15 \mathrm{~m}$ from a secondary entrance (Table 1, Figure 2). All specimens were found near tiny crevasses on the cave walls, showing high mobility, especially under bright light and not in apparent association with any specific benthic species.

\subsubsection{Remarks}

Liechtenstein's goby is a rare cryptobenthic gobiid reported in approximately 20 published records, spanning from the Balearic Islands to the Aegean Sea [12,13,20,22-27]. Its known distribution range, though, is fragmented due to its exclusively cryptic habit $[5,28]$. The species has been assessed as of "Least Concern" in the IUCN Red List of Threatened 
Species, with an unknown population trend [28]. In the Aegean Sea, this species has been reported from its southmost border, the island of Crete [23] and its northmost area, Chalkidiki Peninsula [29], as well as from Lesvos Island [13,24] in Greece and Sığacık Bay in Turkey [26]. The present report is the fifth record of Liechtenstein's goby in the eastern Mediterranean Sea. Even though C. liechtensteini can be found in other cryptic habitats [5], in caves it is mostly seen on the walls and ceiling, within crevasses or biogenic structures like rhodophyte thickets, branching bryozoans, sponge canals, and holes of the boring bivalve Lithophaga lithophaga (Linnaeus, 1758) [10,13,24]. This is the fourth published record of C. liechtensteini from Greece.

\subsection{Didogobius splechtnai (Ahnelt and Patzner, 1995)}

\subsubsection{Diagnosis}

Body mostly dark brown with three moderately broad pale-to-whitish bars and a very thin one at the base of the caudal fin, the first bar immediately at front of the first dorsal fin and extending into the ventral half of pectoral fins (Figure 3) [30].

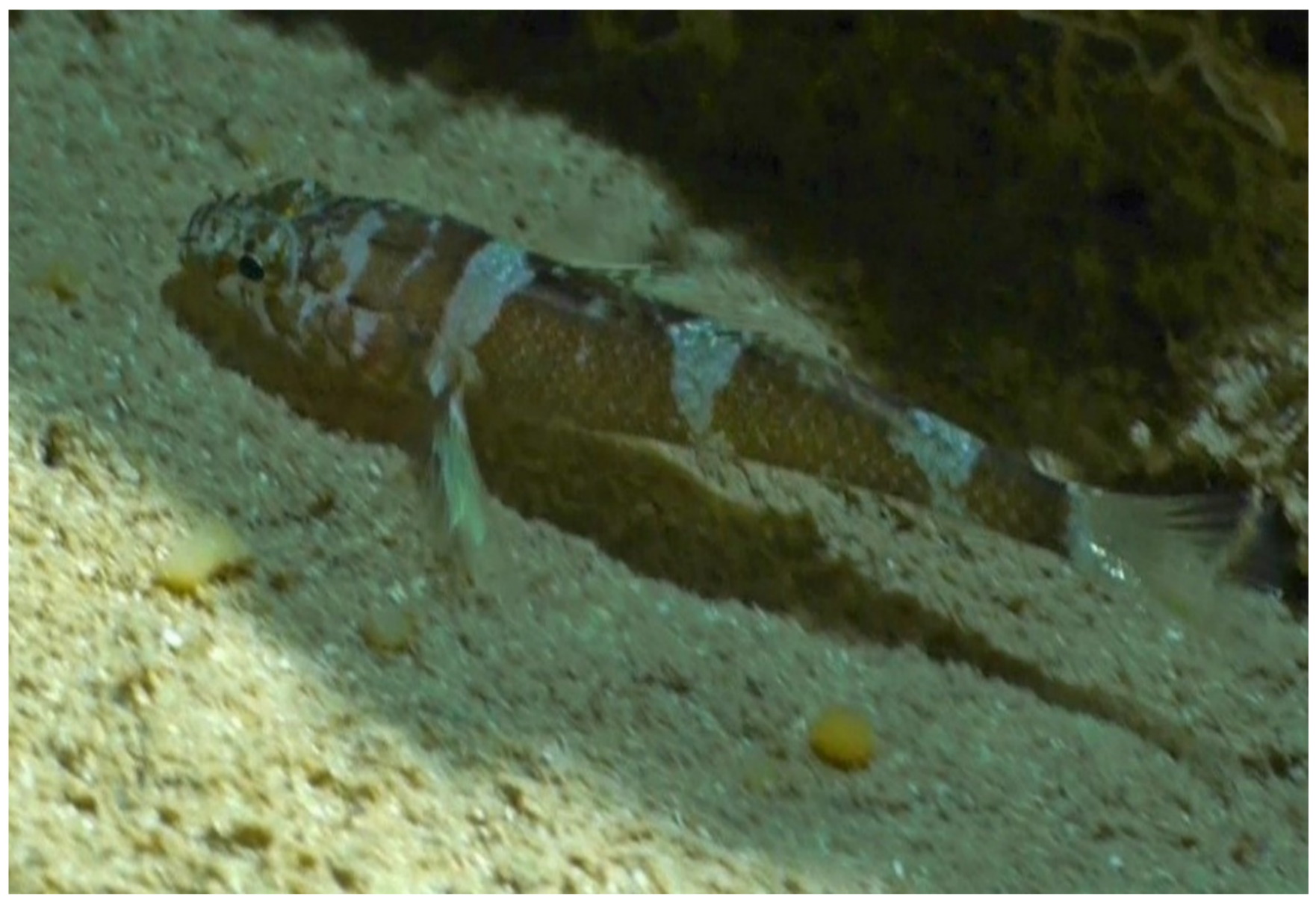

Figure 3. Didogobius splechtnai photographed in Nereid cave, N. Crete. Photo by I. Glampedakis.

\subsubsection{Morphological, Geographical, and Ecological Data}

Three D. splechtnai specimens were observed and photographed in 2010 at the entrance zone of the Nereid cave in Crete. Three additional specimens were recorded at the inner sections of two caves in the Agios Efstathios and Polyaigos Islets, close to Milos Island (Table 1). All specimens were observed on shelves of the cave walls, near or inside a crevice, on rocky and sandy substrates (Figure 3), at depths ranging from 1 to $23 \mathrm{~m}$ and a distance of 2-25 $\mathrm{m}$ from the cave entrance. Even with toned-down light and a silent approach, it 
took multiple attempts to capture them on camera due to the shy behavior of the species. These are the first published records of D. splechtnai from Greek waters.

\subsubsection{Remarks}

Didogobius splechtnai is assigned to the "Least Concern" category in the IUCN Red List of Threatened Species, with an unknown population trend [31], and its distribution extends from the Balearic Islands to the Aegean Sea [10,22,27,32-39]. This species is known to live in caves from 4 to $55 \mathrm{~m}$ [22,32], either on sandy bottoms or on little shelves and cave walls, but nearly always close to holes or crevices [6,32,38].

\subsection{Gammogobius steinitzi (Bath, 1971) \\ 3.3.1. Diagnosis}

Body brownish-yellow, with seven lateral, vertical pale stripes: the first in front of the caudal fin origin, the seventh beginning at the origin of the first dorsal fin; two more bands on the predorsal area; and three bars on the cheek spreading down from the eye (Figure 4) [23].

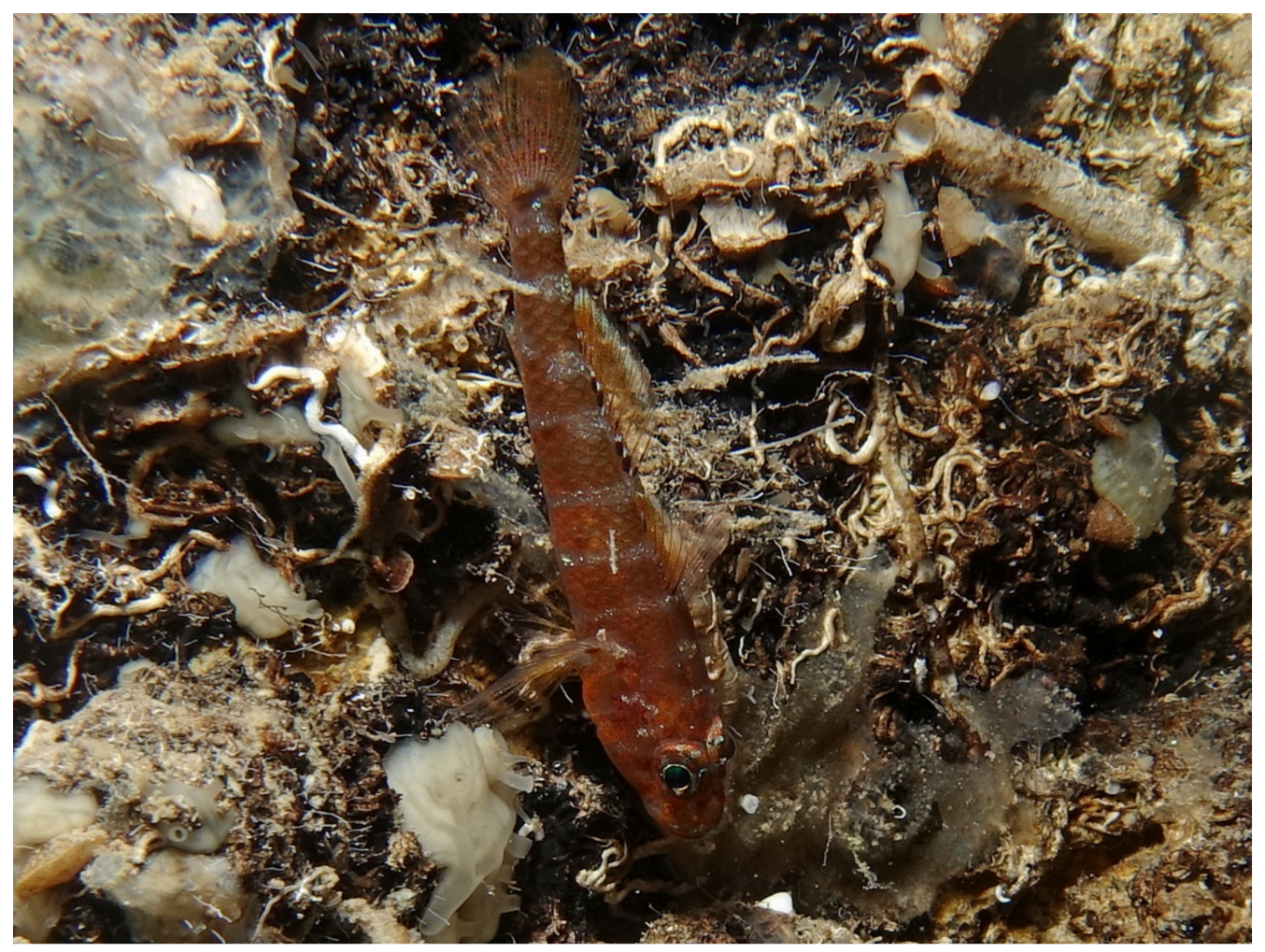

Figure 4. Gammogobius steinitzi photographed in Neptune's cave, Karpathos Island. Photo by M. Ragkousis.

\subsubsection{Morphological, Geographical, and Ecological Data}

Five Steinitz's gobies were recorded in four marine caves in the Crete, Karpathos, Kalymnos, and Polyaigos islands (Table 1, Figure 4). The specimens were found at the entrance zone and semi-dark sections of the caves, at a distance of 15-45 $\mathrm{m}$ from the entrance. All specimens were photographed on cave walls with nukes and crevices.

\subsubsection{Remarks}

Steinitz's goby has been assigned to the "Least Concern" category in the IUCN Red List of Threatened Species, with an unknown population trend [40]. It has been reported along the north Mediterranean coastline from Spain to Turkey [6,15,23,30,33,41-45] and has even been found in the Black Sea [14]. It is a cryptic goby that is known exclusively 
from the marine caves of the Mediterranean and the Black Sea. Similar to our observations, most published records reported G. steinitzi on cave walls and ceilings, close to small holes and crevasses. This is the second published record of G. steinitzi from Greek waters.

\subsection{Thorogobius ephippiatus (Lowe, 1839)}

\subsubsection{Diagnosis}

Head and body water whitish, pale fawn to sandy; there are brown-orange, brick-red to brown-purple blotches on its head and body, the largest along the lateral midline and the dorsal fin bases, with smaller ones on the predorsal area and head (Figure 5) [18].

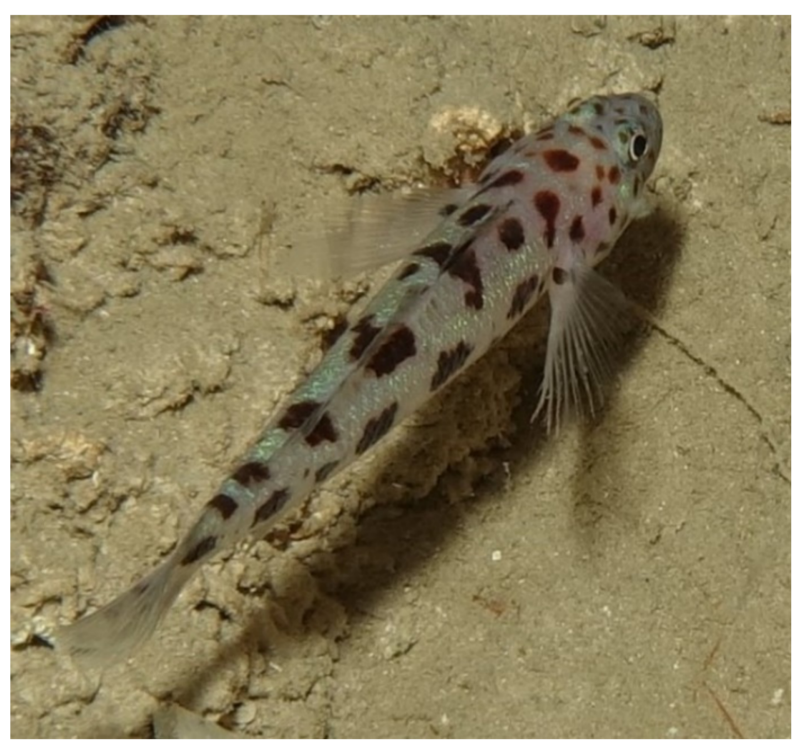

(a)

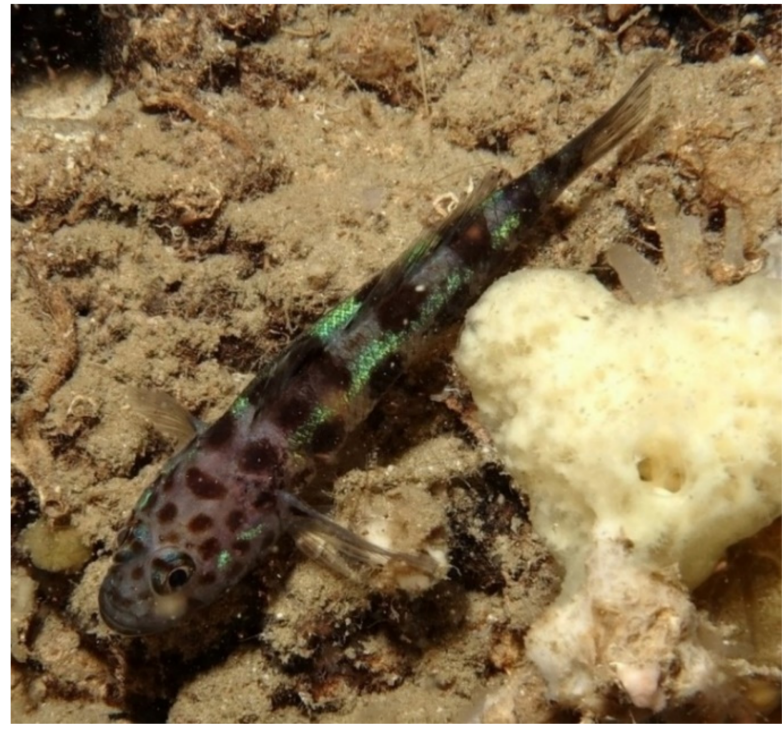

(b)

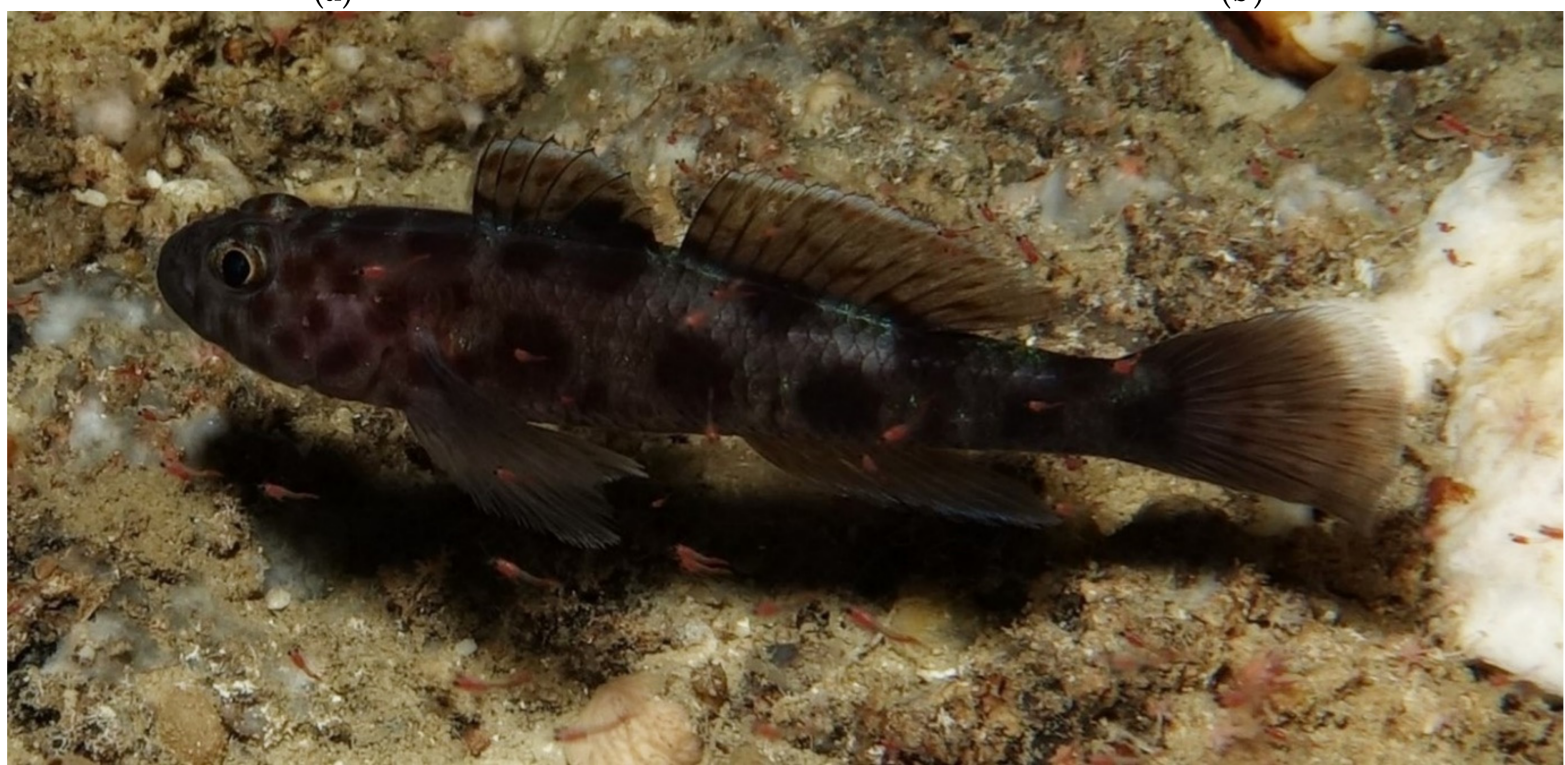

(c)

Figure 5. Thorogobius ephippiatus from the dark interior of the caves of the Pantieronissi (a) and Polyaigos islets (b). Several mysids are also visible in (c). Photos by M. Ragkousis.

\subsubsection{Morphological, Geographical, and Ecological Data}

During several surveys, a total of 28 T. ephippiatus individuals were observed at 10 marine caves of Greece (Table 1). All reported individuals were spotted at a depth range of 2-23 $\mathrm{m}$, from the entrance zone to dark sections of the studied caves. Their preference 
for sandy or muddy substrates is noteworthy. In the Pantieronissi cave, their predatory behavior was observed, with two individuals seen preying on mysids (Mysida), some of which can be seen in Figure 5c.

\subsubsection{Remarks}

Thorogobius ephippiatus has been sporadically reported in the Eastern Mediterranean Sea $[13,23,46,47]$ and is categorized as "Least Concern" in the IUCN Red List of Threatened Species, with a presumed stable population trend globally [48]. It constitutes a solitary speleophilic goby whose distribution spans from the northeastern Atlantic Ocean to Cyprus in the Eastern Mediterranean Sea [24,49]. It is mostly observed in caves but also in dark crevices in shallow water [11-13,23].

\subsection{Microlipophrys nigriceps (Vinciguerra, 1883)}

\subsubsection{Diagnosis}

The only recorded individual had a distinct orangish-red-colored body; large eyes protruding high from its forehead; irregular dark-reddish spots displayed along its whitish head; dorsal fin long, present almost along entire body length and pectoral fins transparent with red rays. The characters match only M. nigriceps among Mediterranean Blenniidae (Figure 6) [50]. Additionally, within the ichthyofauna of the Mediterranean Sea, M. nigriceps can only be misidentified with T. melanurum; however, the two can easily be distinguished by the two dorsal fins in blenny $M$. nigriceps vs. three dorsal fins in the three-fin blenny, T. melanurum [51].

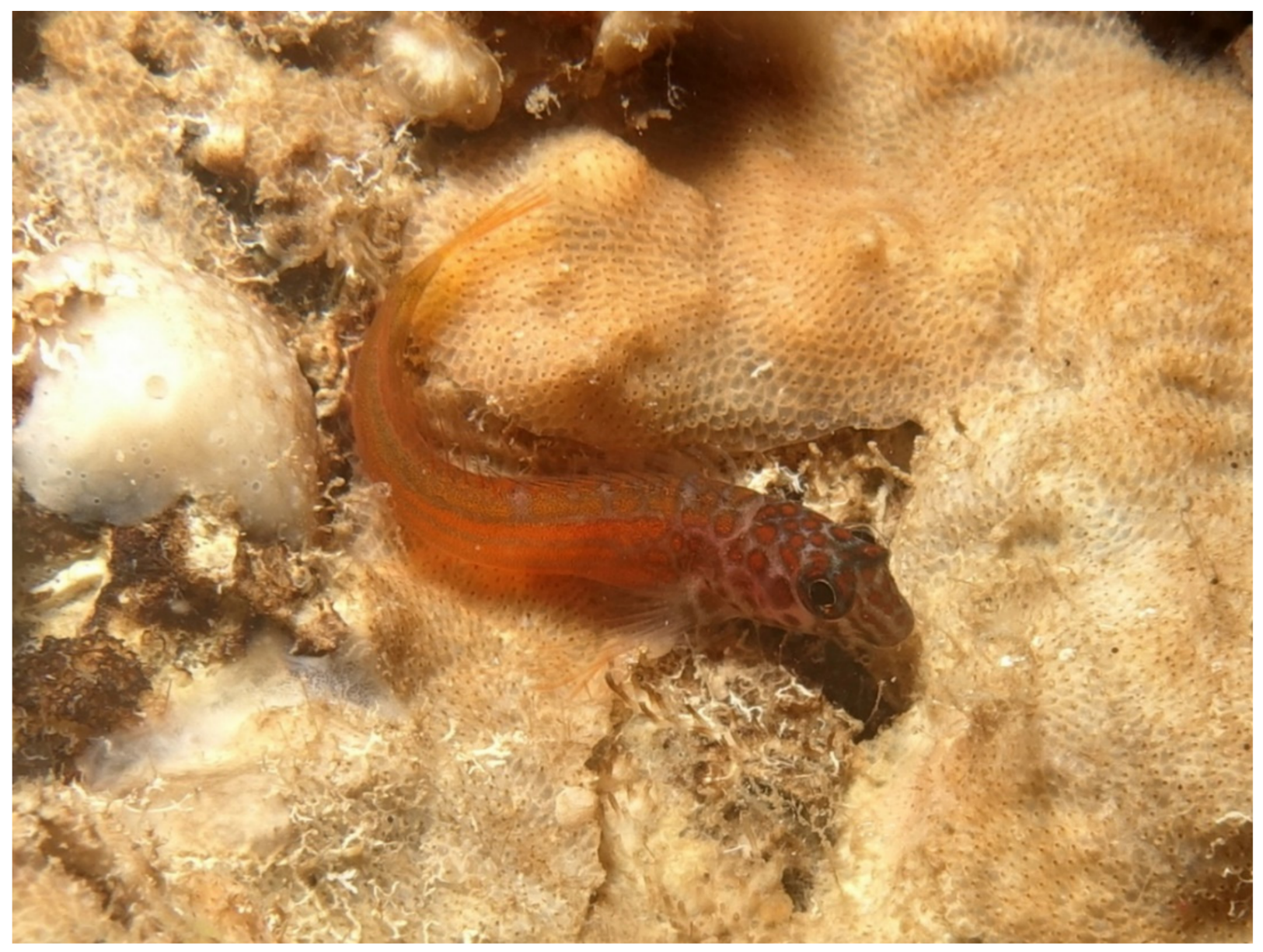

Figure 6. Microlipophrys nigriceps from the semi-dark zone in Seal's Cave of Rhodes Island. Photo by M. Ragkousis. 


\subsubsection{Morphological, Geographical, and Ecological Data}

An individual of the inconspicuous species M. nigriceps was photographed (Figure 6) at $11 \mathrm{~m}$ depth in the semi-dark zone in Seal's cave of Rhodes Island, Dodecanese, clinging onto the cave walls.

\subsubsection{Remarks}

The black-headed blenny M. nigriceps is a scarcely recorded sciaphilic species, endemic to the Mediterranean Sea [5]. It is known to inhabit dimly lit biotopes such as crevices, caves, caverns, and underneath pebbles. More specifically, M. nigriceps has been reported in the Balearic Islands, Spain [10], France [52], Italy [11,12], Croatia [45,53], Montenegro [54], Greece [47], and Turkey [46,55]. Although it appears in shallow waters, there is a dearth of knowledge regarding $M$. nigriceps and its population trends due to its small body size and cryptic behavior. M. nigriceps is assessed as "Least Concern" in the IUCN Red List of Threatened Species [56]. Through the present study we report the second record of this species from a marine cave of the Eastern Mediterranean Sea [4], following a recent study from Turkey ([55] as Lipophrys nigriceps).

\subsection{Tripterygion melanurum (Guichenot, 1850)}

\subsubsection{Diagnosis}

Body of both sexes permanently red; its head is black or black-spotted; dark bars across the flanks are absent; its caudal peduncle lacks a dark spot [57] (Figure 7). From fishes of other fish families in the Mediterranean Sea, the three-fin blenny T. melanurum can only be misidentified with the blenny $M$. nigriceps. However, they are easily distinguished by the three dorsal fins in T. melanurum vs. the two dorsal fins in blenny M. nigriceps [51].

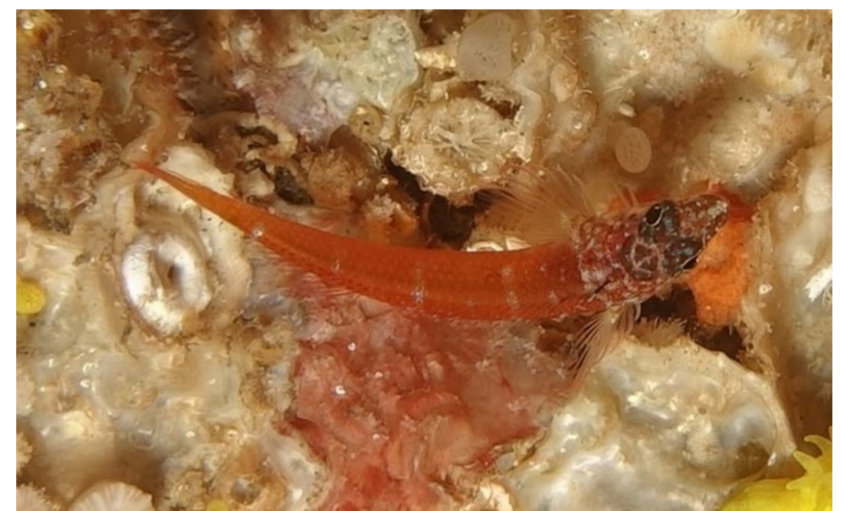

(a)

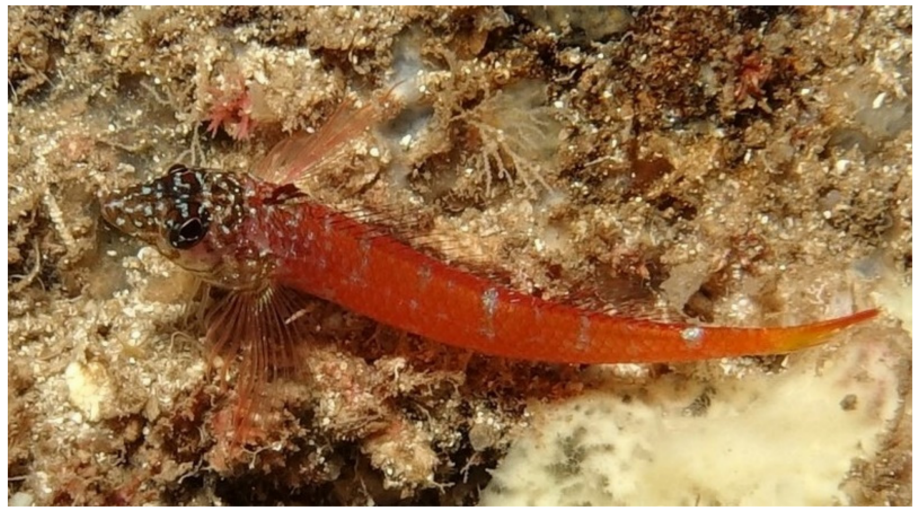

(b)

Figure 7. Tripterygion melanurum photographed in Seal's cave, Samos Island (a) and Agios Efstathios cave, Milos Island (b). Photos by M. Ragkousis.

\subsubsection{Morphological, Geographical, and Ecological Data}

Fourteen individuals were observed in eight different caves at the Polyaigos, Kalymnos, Samos, Milos, Skyros, Karpathos, and Pantieronissi islands/islets, as seen in Table 1. All T. melanurum specimens were found at the cave entrance and semi-dark cave zones, at a depth of 1-5 m. As expected, all 14 specimens were observed on the walls and ceilings of the caves.

\subsubsection{Remarks}

Tripterygion melanurum is a three-fin blenny endemic to the Mediterranean Sea, classified as a "Least Concern" species in the IUCN Red List, with a presumably stable population trend [58]. It has been reported throughout the Aegean Sea [47,59] as well as from caves in Croatia [53], Italy [60], Lebanon [61], and Turkey [25]. Tripterygion melanurum rarely 
exceeds $6 \mathrm{~cm}$ in length with adults mostly found in low-light areas, usually on walls and ceilings [59]. They are suction feeders, preying on small invertebrates including amphipods, harpacticoids, caprellids, and tanaidaceans [62].

\subsection{Grammonus ater (Risso, 1810)}

\subsubsection{Diagnosis}

Among a few species of family Bythitidae known to inhabit the Mediterranean, G. ater is the only species occurring on the continental shelf, while other species are bathyal [63]. G. ater is easily distinguished from any other small-size Mediterranean fish on the continental shelf by the combination of a short, dark-colored body, and a caudal fin not just joined, but also indistinct from dorsal and anal fins [63] (Figure 8). Gaidropsarus mediterraneus (Linnaeus, 1758) is the only fish among fish families in the Mediterranean Sea that occurs in similar habitats and superficially resembles G. ater by coloration and body shape. However, on photographs, G. mediterraneus is easily distinguished from G. ater by a depressed and more slender head, elongated body, and distinct caudal fin [51].

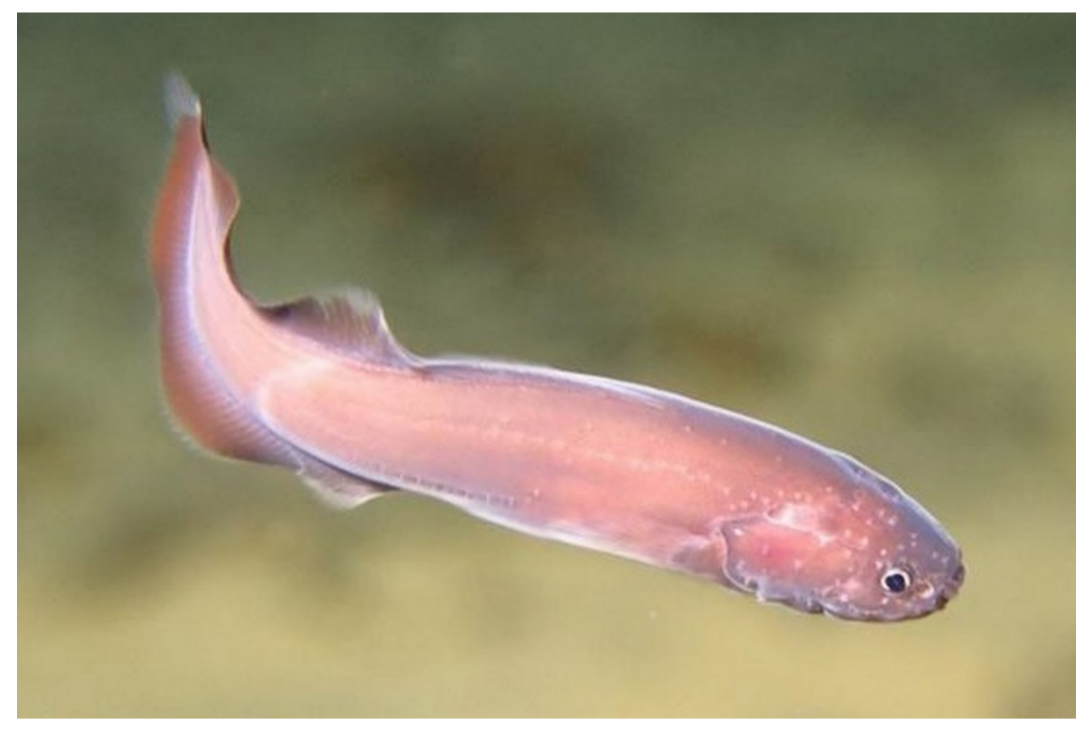

(a)

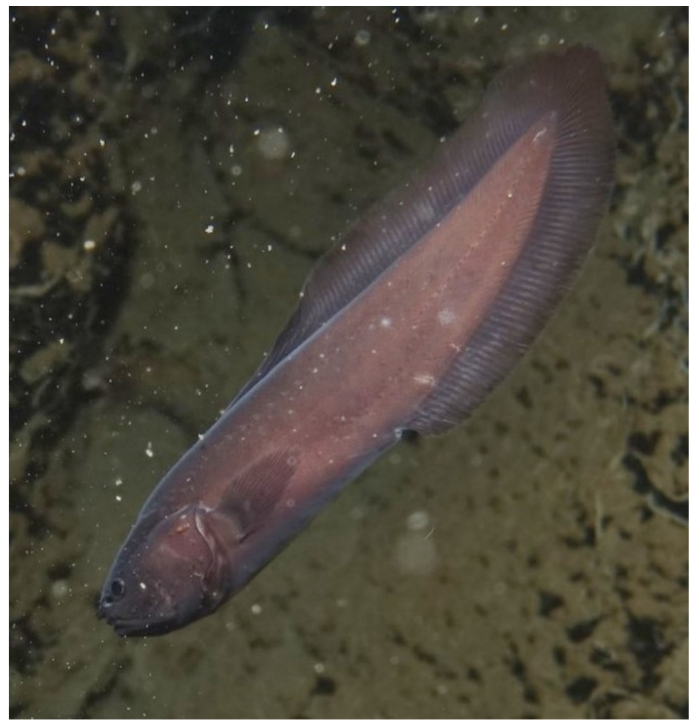

(b)

Figure 8. Grammonus ater photographed in Elephant cave, Crete (a) and Pantieronissi cave, Cyclades (b). Photos by D. Miriokefalitakis (a) and M. Ragkousis (b).

\subsubsection{Morphological, Geographical, and Ecological Data}

Seven individuals were observed in seven marine caves at the south and north coasts of Crete, the islets Pantieronissi, Agios Efstathios, and Polyaigos in the Cyclades, and Kalymnos Island in the Dodecanese, within a depth range of 2-25 m (Table 1). All records consisted of solitary individuals swimming at the darkest cave parts, 10-60 m from the cave entrance. Noteworthy, one reported individual from Pantieronissi cave bore an unidentified parasite attached to its left operculum.

\subsubsection{Remarks}

Grammonus ater (Risso, 1810), first described as Oligopus ater, constitutes a cavedwelling and highly cryptic fish, endemic to the Mediterranean Sea, which belongs to the deep-sea family Bythitidae. Until recently, its known distribution range spanned from the Azores Archipelago ([64] remains unverified) and the Balearic Islands to the Adriatic Sea. Only Pliocene fossils of the species had been found in the Eastern Mediterranean Sea from the islands of Crete and Rhodes [65,66]. However, recent studies in marine caves of the Aegean and Levantine seas brought to light living individuals from Crete [13] 
and Cyprus [49]. It is assessed as "Least Concern" in the IUCN Red List of Threatened Species, with an unknown population trend [67]. Until today, this speleophilic fish has been recorded in 23 marine caves of Spain, France, Italy, Croatia, Greece, and Cyprus (see Table 1 in [13]; [47,66-69]), at a depth range of 2-30 m. The seven new Aegean records presented in this study raise the total number of marine caves reported to harbor G. ater to 30 .

\subsection{Lepadogaster cf. lepadogaster (Bonnaterre, 1788)}

3.8.1. Diagnosis

The only recorded individual had a distinct head shape of clingfish genus Lepadogaster, easily distinguished from any other small-size Mediterranean fish on the continental shelf (Figure 9) [70]. A prominent cirrus projecting from the rim of its anterior nostril distinguishes the individual in the photo from L. candolii (Risso, 1810) (Figure 9) [70]. According to Wagner et al. [71], L. lepadogaster can be distinguished from its sister species L. purpurea (Bonnaterre, 1788) by morphometric features such as body and head length and body width, as well as its sucking disk width and the number of papillae surrounding it, none of which are visible in Figure 9. Therefore, the species was tentatively identified from the photograph as L. cf. lepadogaster based on the lowest longitudinal bluish line on the head not crossing over the eye below the pupil (compare Figure 9 with Figure 2A,B in [71]). For the positive identification of $L$. cf. lepadogaster from marine caves, sampled specimens or photographs from a better angle are needed.

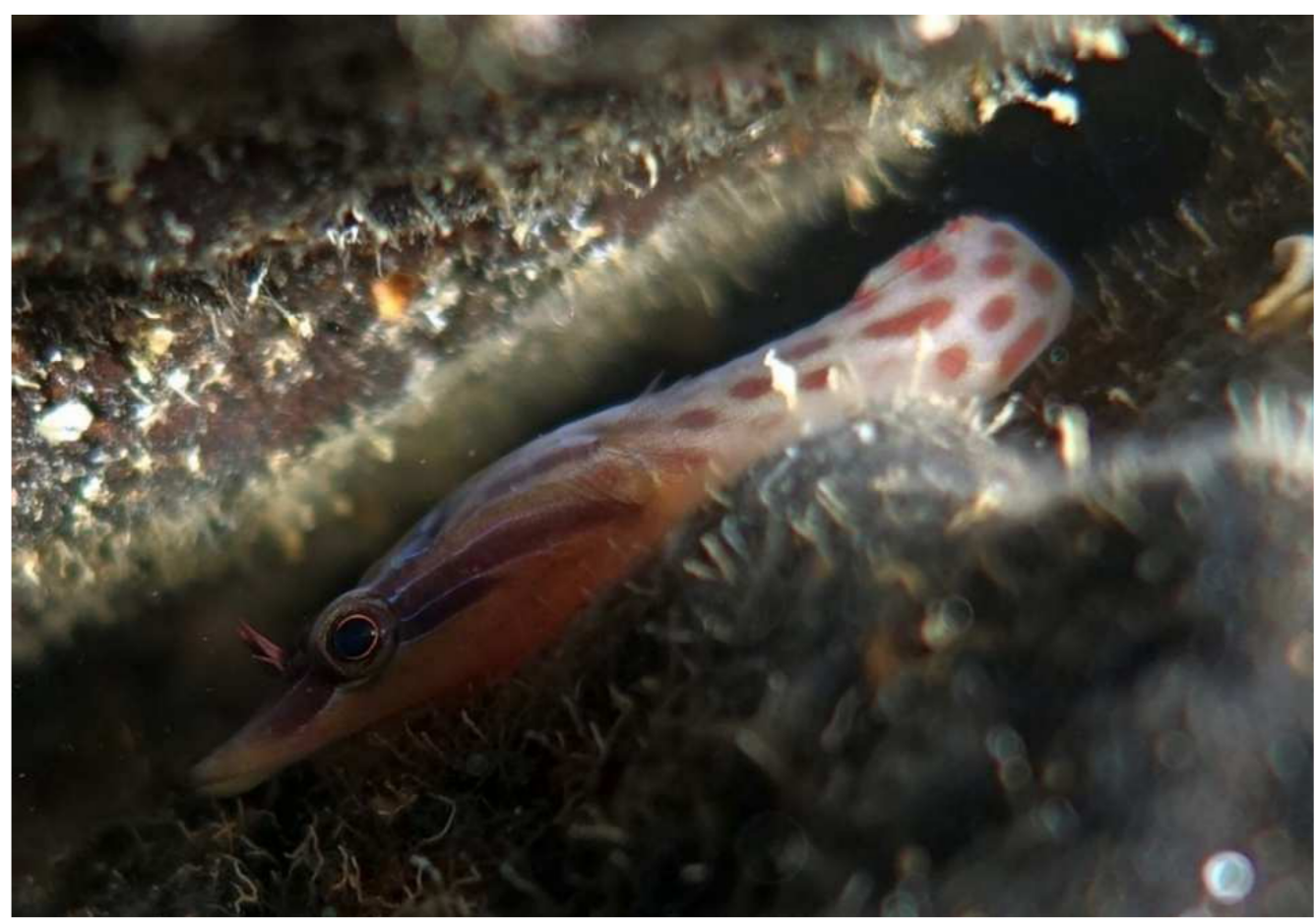

Figure 9. Lepadogaster cf. lepadogaster photographed in a shallow dark cave on Kalymnos Island. Photo by M. Ragkousis.

\subsubsection{Morphological, Geographical, and Ecological Data}

A single individual of the cryptobenthic fish $L$. cf. lepadogaster was recorded inside of a shallow marine cave on Kalymnos Island, Dodecanese. It was observed only a few centimeters $(>0.3 \mathrm{~m})$ from the water surface, between boulders, cobbles, and pebbles created by a partial collapse of the cave's ceiling. 


\subsubsection{Remarks}

According to Wagner et al. [71], all representatives of the genus Lepadogaster inhabit shadowy environments like crevices, seagrass rhizomes, pebble interstices, and underneath boulders. The shore clingfish L. lepadogaster constitutes an inconspicuous species, which for many years was described as the subspecies L. lepadogaster lepadogaster, closely related to L. lepadogaster purpurea (Briggs, 1955). Henriques et al. [72] proposed that the two subspecies are actually distinct species based on their morphological differences. A few years later, Almada et al. [73] documented their molecular dissimilarities. The L. lepadogaster distribution range spans from the European and northwestern African and Atlantic coasts to the Mediterranean and Black seas [71]. The presence of the species was recently recorded in Greek waters from two locations in Crete and two more in Attica [71]. It has been assigned as "Least Concern" in the IUCN Red List of Threatened Species, with an unknown population trend [74]. In the present study, an additional record of this species is reported from Kalymnos Island. While L. lepadogaster was previously recorded from marine caves of Crimea [75] and the Mediterranean coast of Israel [76], only L. candolii was recorded in a single marine cave of the Aegean Sea, associated with the sponge Aplysina aerophoba (Nardo, 1833) [4,24]. Thus, this study constitutes the second record of a clingfish species in a marine cave of the Aegean Sea.

\section{Discussion}

Fishes in Mediterranean marine caves can be assigned to three main ecological categories according to their degree of association with the cave habitat: (1) Species typically inhabiting marine caves; (2) Species associated with cryptic habitats (e.g., crevices and fissures), also frequently found in caves; (3) Nectobenthic species inhabiting rocky reefs that can occasionally be found in caves, but usually close to the entrance [12,27]. Among the species recorded in this study, Grammonus ater, Gammogobius steinitzi, and Didogobius splechtnai belong to the first category; and Corcyrogobius liechtensteini, Thorogobius ephippiatus, Microlipophrys nigriceps, and Tripterygion melanurum belong to the second category. Lepadogaster lepadogaster, with only two previous records from marine caves in the Black Sea [75], and Israel [76], is associated with very shallow cryptic habitats and therefore can be found in caves, in cases of habitat overlapping, when marine caves reach the intertidal zones.

The study of mobile fauna in several marine caves of the northeastern Mediterranean Sea revealed new findings, such as the first record of D. splechtnai from Greek waters, as well as several rarely reported species. Steinitz's goby, G. steinitzi, is reported for the second time in Greece, significantly expanding its known distribution throughout the southern Aegean Sea, from Crete to the Cyclades and Dodecanese islands. Despite the fact that several marine caves were studied in Greece during the last decade, T. ephippiatus was reported from only one cave of Lesvos Island in the North Aegean Sea [13]. With the current study, we show that T. ephippiatus is widely distributed throughout the Aegean and northern Levantine Sea (28 individuals from 10 marine caves), filling distribution gaps regarding this highly cryptic goby.

Grammonus ater is usually observed as a solitary individual, in accordance with our observations, although Bori et al. [77] noted that it can reach a density of 10 individuals in a single cave during the reproductive season (April-June). This species was observed in the overwhelming majority of the visited caves as long as totally dark conditions were available. Thus, its rare sightings could be attributed to its preference for exclusively dark cryptic habitats such as the innermost sections of marine caves and deep-sea within the depth range of $0-700 \mathrm{~m}[13,78,79]$. Our study in the marine caves of the northeastern Mediterranean Sea resulted in a 23\% increase in Mediterranean cave records (from 23 to 30), revealing that the species is more common than previously thought in the eastern basin, but only recently observed due to a regional time lag in marine cave research [3]. Further investigation of marine caves may provide more information about the species' behavior and physiology. 
We believe that the herein notable documented increase in the known distribution range of the above-mentioned cryptobenthic species is related to the extensive amount of time spent surveying the shallow caves. Our extended in situ observations revealed interesting behavioral and ecological aspects for some species. For instance, the shy behavior of D. splechtnai challenged its photographic capture even with toned-down light and a silent approach. The leopard-spotted goby, T. ephippiatus, was observed to prey on mysids in the Pantieronissi cave (Figure 5c). In four marine caves (Agios Efstathios, Polyaigos, Kalymnos, and Pantieronissi islets/islands), the speleophilic G. ater was observed only after careful investigation inside small holes and fissures not larger than $5 \mathrm{~cm}$ on walls of the darkest cave sections, including a parasitized individual, and revealing a notably cryptic habit and shy behavior.

The species $M$. nigriceps and T. melanurum are very similar in coloration and patterns. Though no evidence has been presented here or elsewhere in the published literature, to support a case of mimicry or a possible converging evolution path [80], a devoted study should be manifested in order to understand the enigmatic relationship between these two species.

Among the studied marine caves, that of Pantieronissi Islet, close to Paros, presented the highest diversity and abundance of cryptobenthic fish (14 individuals belonging to 4 species), followed by the Nereid cave, Chania, North Crete (11 individuals belonging to 4 species). Moreover, during the underwater survey in the dark zone of the Pantieronissi cave, we noticed many reddish-brownish, tiny gobiids of unknown identity that avoided the camera lens and thus were not reported in this study. The high abundance of cryptobenthic fish in these caves highlights their importance for future research and conservation initiatives.

All cryptobenthic species reported in this study have been assigned to the "Least Concern" category in the IUCN Red List of Threatened Species mainly due to the presumed lack of threats (e.g., [31]). However, there are only scarce population assessments and no regular monitoring of these species to reliably evaluate their population trends and statuses. The eastern Mediterranean is a hotspot of biological invasions [81] and many caves have been highly affected, with invasive alien fish often dominating the cave ichthyofauna ([82] and authors' unpublished data). The impacts of invasive species to the native cave fauna through trophic interactions or modification of energy flows remain understudied. Furthermore, the eastern Mediterranean, in particular in its warm end, is greatly affected by climate change, with multiple native species collapses [83] and domination by alien species $[81,84,85]$. Such cumulative impacts from biological invasions, climate change, and other local anthropogenic stressors [86] are expected to increase in the future and substantially affect the yet-understudied populations of many cryptobenthic species.

Further research on the mobile fauna of marine caves is urgently needed to fill regional gaps and increase our understanding of cryptic biota, their ecological habits, conservation status, and future risks. Protection of marine caves is required by European legislation (i.e., Habitats Directive) and is included in systematic conservation plans [87,88], but a deeper knowledge of their unique biodiversity will be valuable for the prioritization of specific caves for conservation. This is a timely consideration in view of the future expansion of the European network of marine-protected areas to cover $30 \%$ of the total European marine area, as demanded by the new European Biodiversity Strategy for 2030.

Author Contributions: Conceptualization, M.R., M.D., and V.G.; sampling, M.R., M.D., and V.G.; validation, M.K.; writing-original draft preparation, M.R., M.D., and V.G.; writing-review and editing, M.K. and S.K.; supervision, V.G. and S.K.; project administration, S.K.; funding acquisition, S.K. All authors have read and agreed to the published version of the manuscript.

Funding: The present study was supported by the Hellenic Foundation for Research and Innovation (H.F.R.I.) under the "First Call for H.F.R.I. Research Projects to support Faculty members and Researchers and the procurement of high-cost research equipment grant" (Project ALAS-'ALiens in the Aegean-a Sea under siege'; Project Number: HFRI-FM17-1597; [17]). Underwater observations 
in 2016 were made in the framework of the MARISCA project, co-funded (85\%) by EEA GRANTS, 2009-2014, and the Public Investments Program (PIP) of the Hellenic Republic (15\%).

Institutional Review Board Statement: Not applicable.

Informed Consent Statement: Not applicable.

Data Availability Statement: All available data are provided in Table 1.

Acknowledgments: We are grateful to Ioulios Glampedakis for providing underwater photographs of Didogobius splechtnai, Gammogobius steinitzi, Grammonus ater, and Thorogobius ephippiatus from Crete, and to Dimitris Miriokefalitakis from Evelin Dive Center for providing an underwater photograph of Grammonus ater. We also thank Maria Sini and Thanos Dailianis for their valuable help during the 2016 sampling expedition in the frame of the MARISCA project. Vasilis Gerovasileiou would like to thank Alen Soldo for his kind invitation to participate in the Special Issue entitled "Revealing the Biodiversity of Hidden Marine Habitats" in JMSE.

Conflicts of Interest: The authors declare no conflict of interest.

\section{References}

1. Gerovasileiou, V.; Voultsiadou, E. Marine caves of the Mediterranean Sea: A sponge biodiversity reservoir within a biodiversity hotspot. PLoS ONE 2012, 7, e39873. [CrossRef]

2. Nepote, E.; Bianchi, C.N.; Morri, C.; Ferrari, M.; Montefalcone, M. Impact of a harbour construction on the benthic community of two shallow marine caves. Mar. Pollut. Bull. 2017, 114, 35-45. [CrossRef]

3. Gerovasileiou, V.; Bianchi, C. Mediterranean marine caves: A synthesis of current knowledge. Oceanogr. Mar. Biol. Annu. Rev. 2021, 59.

4. Gerovasileiou, V.; Chintiroglou, C.; Vafidis, D.; Koutsoubas, D.; Sini, M.; Dailianis, T.; Issaris, Y.; Akritopoulou, E.; Dimarchopoulou, D.; Voutsiadou, E. Census of biodiversity in marine caves of the eastern Mediterranean Sea. Mediterr. Mar. Sci. 2015, 16, 245-265. [CrossRef]

5. Kovačić, M.; Patzner, R.A.; Schliewen, U. A first quantitative assessment of the ecology of cryptobenthic fishes in the Mediterranean Sea. Mar. Biol. 2012, 159, 2731-2742. [CrossRef]

6. Patzner, R.A. Habitat utilization and depth distribution of small cryptobenthic fishes (Blenniidae, Gobiesocidae, Gobiidae, Tripterygiidae) in Ibiza (western Mediterranean Sea). Environ. Biol. Fishes 1999, 55, 207-214. [CrossRef]

7. Kovačić, M.; Patzner, R.A. North-eastern Atlantic and Mediterranean gobies. In The Biology of Gobies; Patzner, R.A., VanTassell, J.L., Kovačić, M., Kapoor, B.G., Eds.; Science Publishers: New York, NY, USA; CRC Press: New York, NY, USA; Taylor \& Francis Group: New York, NY, USA, 2011; pp. 177-206.

8. Miller, P.J. Adaptiveness and implications of small size in teleosts. Symp. Zool. Soc. Lond. 1979, 44, $263-306$.

9. Depczynski, M.; Bellwood, D.R. The role of cryptobenthic reef fishes in coral reef trophodynamics. Mar. Ecol. Prog. Ser. 2003, 256, 183-191. [CrossRef]

10. Herler, J.; Patzner, R.A.; Ahnelt, H.; Hilgers, H. Habitat selection and ecology of two speleophilic gobiid fishes (Pisces: Gobiidae) from the western Mediterranean Sea. Mar. Ecol. 1999, 20, 49-62. [CrossRef]

11. Bussotti, S.; Guidetti, P. Do Mediterranean fish assemblages associated with marine caves and rocky cliffs differ? Estuar. Coast. Shelf Sci. 2009, 81, 65-73. [CrossRef]

12. Bussotti, S.; Di Franco, A.; Francour, P.; Guidetti, P. Fish assemblages of Mediterranean marine caves. PLoS ONE 2015, 10, e0122632. [CrossRef]

13. Gerovasileiou, V.; Ganias, K.; Dailianis, T.; Voultsiadou, E. Occurrence of some rarely reported fish species in eastern Mediterranean marine caves. Cah. Biol. Mar. 2015, 56, 381-387.

14. Kovtun, O.A.; Manilo, L.G. Mediterranean fish-Gammogobius steinitzi Bath, 1971 (Actinopterygii: Perciformes: Gobiidae)-A new representative of the black sea ichthyofauna. Acta Ichthyol. Piscat. 2013, 43, 307-314. [CrossRef]

15. Engin, S.; Irmak, E.; Seyhan, D.; Akdemir, T.; Keskin, A.C. Gobiid fishes of the coastal zone of the Northeastern Aegean Sea. Mar. Biodivers. 2018, 48, 1073-1084. [CrossRef]

16. Sini, M.; Katsanevakis, S.; Koukourouvli, N.; Gerovasileiou, V.; Dailianis, T.; Buhl-Mortensen, L.; Damalas, D.; Dendrinos, P.; Dimas, X.; Frantzis, A.; et al. Assembling ecological pieces to reconstruct the conservation puzzle of the Aegean Sea. Front. Mar. Sci. 2017, 4, 347. [CrossRef]

17. Katsanevakis, S.; Tsirintanis, K.; Sini, M.; Gerovasileiou, V.; Koukourouvli, N. Aliens in the Aegean-A sea under siege (ALAS). Res. Ideas Outcomes 2020, 6, e53057. [CrossRef]

18. Kovačić, M.; Svensen, R. The confirmed and continuous northern distribution of Thorogobius ephippiatus (Teleostei: Gobiidae) with the scientific use of recreational fishing data. J. Appl. Ichthyol. 2018, 34, 691-693. [CrossRef]

19. Haklay, M.M.; Dörler, D.; Heigl, F.; Manzoni, M.; Hecker, S.; Vohland, K. What is citizen science? The challenges of definition. In The Science of Citizen Science; Vohland, K., Land-Zandstra, A., Ceccaroni, L., Lemmens, R., Perelló, J., Ponti, M., Samson, R., Wagenknecht, K., Eds.; Springer: Cham, Switzerland, 2021; pp. 13-33. 
20. Ahnelt, H.; Miller, P.; Patzner, R. Systematics and distribution of two rare Mediterranean gobies, Corcyrogobius liechtensteini and Odondebuenia balearica (Teleostei: Gobiidae). Cybium 1994, 18, 169-176.

21. Herler, J.; Ahnelt, H.; Scsepka, S. Morphologische Untersuchungen an zwei höhlenbewohnenden Meergrundeln (Pisces: Gobiidae) des westlichen Mittelmeeres. Ann. Nat. Mus. Wien Ser. B Bot. Zool. 1999, 101, 489-507.

22. Ahnelt, H.; Dorda, J. Gobioid fishes from the north eastern Atlantic and the Mediterranean: New records and rarely found species. Ann. Nat. Mus. Wien Ser. B Bot. Zool. 2003, 105B, 5-19.

23. Kovačić, M.; Miletić, M.; Papageorgiou, N. A first checklist of gobies from Crete with ten new records. Cybium 2011, 35, 245-253.

24. Gerovasileiou, V.; Chintiroglou, C.C.; Konstantinou, D.; Voultsiadou, E. Sponges as "living hotels" in Mediterranean marine caves. Sci. Mar. 2016, 80, 279-289. [CrossRef]

25. Bilecenoğlu, M. Diversity of cavern fishes at the Eastern Aegean Sea coasts (Turkey): Preliminary observation. In Marine Caves of the Eastern Mediterranean Sea. Biodiversity, Threats and Conservation; Öztürk, B., Ed.; Turkish Marine Research Foundation (TUDAV): Istanbul, Turkey, 2019; pp. 84-90.

26. Bilecenoğlu, M. Two marine fish records of Liechtenstein's goby (Corcyrogobius liechtensteini) and the Atlantic originated sergeant major (Abudefduf saxatilis), new for the Turkish fauna. J. Black Sea Mediterr. Environ. 2016, 22, 259-265.

27. Bussotti, S.; Di Franco, A.; Pey, A.; Vieux-Ingrassia, J.-V.; Planes, S.; Guidetti, P. Distribution patterns of marine cave fishes and the potential role of the cardinal fish Apogon imberbis (Linnaeus, 1758) for cave ecosystem functioning in the western Mediterranean. Aquat. Living Resour. 2017, 30, 1-9. [CrossRef]

28. Kovačić, M.; Williams, J.T.; Herler, J. Corcyrogobius liechtensteini. The IUCN Red List of Threatened Species 2014: E.T194865A49085922. Available online: https:/ / www.iucnredlist.org/species/194865/49085922 (accessed on 4 May 2021).

29. Patzner, R.A. Mediterranean Gobies. Available online: http://www.patzner.sbg.ac.at/Gobiidae/GobiidaeGeneral.htm?fbclid= IwAR1E4lgBa2kemFs9FzBdluNrKKL0PczgOH3fLMrQ7c0h2pxu5XECXHtaJzo (accessed on 4 May 2021).

30. Ahnelt, H.; Patzner, R.A. A new species of Didogobius (Teleostei: Gobbidae) from the western Mediterranean. Cybium 1995, 19, 95-102.

31. Kovačić, M.; Williams, J.T.; Herler, J. Didogobius splechtnai. The IUCN Red List of Threatened Species 2014: E.T194869A49085301. Available online: https://www.iucnredlist.org/species/194869/49085301 (accessed on 4 May 2021).

32. Colombo, M.; Langeneck, J. The importance of underwater photography in detecting cryptobenthic species: New in situ records of some gobies (Teleostei: Gobiidae) from Italian Seas with ecological notes. Acta Adriat. 2013, 54, 101-110.

33. Scsepka, S.; Ahnelt, H.; Herler, J.; Hilgers, H. Morphology of two rare Mediterranean gobiid fishes (Teleostei: Gobiidae). Cybium 1999, 23, 169-187.

34. Stefanni, S. A new record of Didogobius splechtnai Ahnelt \& Patzner, 1995 (Gobiidae) from the central Mediterranean Sea. Cybium 1999, 23, 105-107.

35. Herler, J.; Patzner, R.A. New records of Didogobius splechtnai (Gobiidae) from the Tyrrhenian and northern Adriatic Sea. Cybium 2002, 26, 153-155.

36. Kovačić, M. An annotated checklist of the family Gobiidae in the Adriatic Sea. Ann. Ser. Hist. Nat. 2005, 15, 21-44.

37. Francour, P.; Bilecenoglu, M.; Kaya, M. In situ observation on new and rare gobies from the Eastern Mediterranean Sea. Rapp. Comm. Int. Mer Médit. 2007, 38, 1-28.

38. Francour, P. First records of Didogobius splechtnai along the French Mediterranean coast and additional comments about $D$. schlieweni. Acta Ichthyol. Piscat. 2008, 2, 139-141. [CrossRef]

39. Relini, G.; Lanteri, L. Osteichthyes. Biol. Mar. Mediterr. 2010, 17, 649-674.

40. Kovačić, M.; Williams, J.T.; Herler, J. Gammogobius steinitzi. The IUCN Red List of Threatened Species 2014: E.T194871A49085069. Available online: https:/ / www.iucnredlist.org/species/194871/49085069 (accessed on 4 May 2021).

41. Bath, H. Gammogobius steinitzi n. gen. n. sp. aus dem westlichen Mittelmeer. Senckenb. Biol. 1971, 52, $201-210$.

42. Ahnelt, H.; Herler, J.; Scsepka, S.; Patzner, R.A. First records of two rare Mediterranean Gobiidae in the northern Tyrrhenian Sea. Cybium 1998, 22, 183-186.

43. Kovačić, M. Gammogobius steinitzi Bath, 1971, a fish new to the Adriatic Sea. Nat. Croat. 1999, 8, 1-7.

44. Kovačić, M.; Miller, P.J. A new species of Gobius (Teleostei: Gobiidae) from the northern Adriatic Sea. Cybium 2000, 24, 231-239.

45. Arko-Pijevac, M.; Benac, Č.; Kovačić, M.; Kirinčić, M. A submarine cave at the island of Krk (North Adriatic Sea). Nat. Croat. 2001, 10, 163-184.

46. Bilecenoğlu, M.; Kaya, M.; Cihangir, B.; Çiçek, E. An updated checklist of the marine fishes of Turkey. Turk. J. Zool. 2014, 38, 901-929. [CrossRef]

47. Papaconstantinou, C. Fauna Graeciae. An Updated Checklist of the Fishes in the Hellenic Seas; Monographs on Marine Sciences 7; HCMR: Athens, Greece, 2014; pp. 1-340.

48. Williams, J.T.; Herler, J.; Kovačić, M. Thorogobius ephippiatus. The IUCN Red List of Threatened Species 2014: E.T198669A45119519. Available online: https://www.iucnredlist.org/species/198669/45119519 (accessed on 4 May 2021).

49. Gerovasileiou, V.; Akel, E.H.K.; Akyol, O.; Alongi, G.; Azevedo, F.; Babali, N.; Bakiu, R.; Bariche, M.; Bennoui, A.; Castriota, L.; et al. New Mediterranean biodiversity records (July, 2017). Mediterr. Mar. Sci. 2017, 18, 355-384.

50. Tiralongo, F. Blennies of the Mediterranean Sea: Biology and Identification of Blenniidae Clinidae Tripterygiidae, 1st ed.; Independently Published: Avola, Italy, 2020; pp. 1-139.

51. Louisy, P. Europe and Mediterranean Marine Fish. Identification Guide; Editions Ulmer: Paris, France, 2015; pp. 1-512. 
52. Harmelin, J.-G.; Boury-Esnault, N.; Fichez, R.; Vacelet, J.; Zibrowius, H. Communities of a submarine cave at Bagaud Island (Port-Cros National Park, France, Mediterranean). Trav. Sci. Parc Natl. Port. Cros 2003, 19, 117-134.

53. Zavodnik, D.; Pallaoro, A.; Jaklin, A.; Kovačić, M.; Arko-Pjevac, M. A benthos survey of the Senj Archipelago (North Adriatic Sea, Croatia). Acta Adriat. 2005, 46, 3-68.

54. Mačić, V.; Panou, A.; Bundone, L.; Varda, D.; Pavićević, M. First inventory of the semi-submerged marine caves in South Dinarides Karst (Adriatic Coast) and preliminary list of species. Turk. J. Fish. Aquat. Sci. 2019, 19, 765-774. [CrossRef]

55. Özalp, B. Biodiversity of marine caves and cave-like formations around the Northern Aegean islands of Turkey (Gökçeada and Bozca-ada). In Marine Caves of the Eastern Mediterranean Sea. Biodiversity, Threats and Conservation; Publication 53; Turkish Marine Research Foundation (TUDAV): Istanbul, Turkey, 2019; pp. 166-185.

56. Williams, J.T.; Herler, J.; Kovačić, M. Microlipophrys nigriceps. The IUCN Red List of Threatened Species 2014: E.T194854A49090459. Available online: https:/ / www.iucnredlist.org/species/194854/ 49090459 (accessed on 4 May 2021).

57. Wirtz, P. A key to the European Blennioidea. Vie Milieu 1976, 26, 145-156.

58. Holleman, W. Tripterygion melanurum. The IUCN Red List of Threatened Species 2014: E.T194895A49092526. Available online: https: / / www.iucnredlist.org/species/194895/49092526 (accessed on 4 May 2021).

59. Zander, C.D. Tripterygiidae. In Fishes of the North-Eastern Atlantic and the Mediterranean; Whitehead, P.J.P., Bauchot, M.-L., Hureau, J.-C., Nielsen, J., Tortonese, E., Eds.; UNESCO: Paris, France, 1986; Volume 3, pp. 1118-1121.

60. Denitto, F.; Belmonte, G. Le grotte marine del Salento: Censimento 2008. Thalass. Salentina 2008, 31, 105-144.

61. Zenetos, A.; Akel, E.H.K.; Apostolidis, C.; Bilecenoglu, M.; Bitar, G.; Buchet, V.; Chalari, N.; Corsini-Foka, M.; Crocetta, F.; Dogrammatzi, A.; et al. New mediterranean biodiversity records (April 2015). Mediterr. Mar. Sci. 2015, 16, 266-284. [CrossRef]

62. Wirtz, P. The behaviour of the Mediterranean Tripterygion species (Pisces, Blennioidei). Z. Tierpsychol. 1978, 48, 142-174. [CrossRef]

63. Nielsen, J.G. Bythitidae. In Fishes of the North-Eastern Atlantic and the Mediterranean; Whitehead, P.J.P., Bauchot, M.-L., Hureau, J.-C., Nielsen, J., Tortonese, E., Eds.; UNESCO: Paris, France, 1986; Volume 3, pp. 1153-1157.

64. Carneiro, M.; Martins, R.; Landi, M.; Costa, F.O. Updated checklist of marine fishes (Chordata: Craniata) from Portugal and the proposed extension of the Portuguese continental shelf. Eur. J. Taxon. 2014, 73, 1-7. [CrossRef]

65. Agiadi, K.; Koskeridou, E.; Triantaphyllou, M.; Girone, A.; Karakitsios, V. Fish otoliths from the Pliocene Heraklion Basin (Crete Island, Eastern Mediterranean). Geobios 2013, 46, 461-472. [CrossRef]

66. Agiadi, K.; Vasileiou, G.; Koskeridou, E.; Moissette, P.; Cornée, J.J. Coastal fish otoliths from the early Pleistocene of Rhodes (eastern Mediterranean). Geobios 2019, 55, 1-15. [CrossRef]

67. Nielsen, J.; Knudsen, S.; Uiblein, F. Grammonus ater. The IUCN Red List of Threatened Species 2014: E.T194845A49088360. Available online: https:/ / www.iucnredlist.org/species/194845/49088360 (accessed on 4 May 2021).

68. Scotti, G.; Consoli, P.; Esposito, V.; Chemello, R.; Romeo, T.; Andaloro, F. Marine caves of the Southern Tyrrhenian Sea: A first census of benthic biodiversity. J. Mar. Sci. Res. Dev. 2017, 7, 1-9.

69. Jimenez, C.; Achilleos, K.; Petrou, A.; Hadjioannou, L.; Guido, A.; Rosso, A.; Gerovasileiou, V.; Albano, P.G.; Di Franco, D.; Andreou, V.; et al. A dream within a dream: Kakoskali Cave, a unique marine ecosystem in Cyprus (Levantine Sea). In Marine Caves of the Eastern Mediterranean Sea. Biodiversity, Threats and Conservation; Öztürk, B., Ed.; Publication 53; Turkish Marine Research Foundation (TUDAV): Istanbul, Turkey, 2019; pp. 91-110.

70. Briggs, J.C. Gobiesocidae. In Fishes of the North-Eastern Atlantic and the Mediterranean; Whitehead, P.J.P., Bauchot, M.-L., Hureau, J.-C., Nielsen, J., Tortonese, E., Eds.; UNESCO: Paris, France, 1986; Volume 3, pp. 1351-1359.

71. Wagner, M.; Bračun, S.; Kovačić, M.; Iglesias, S.P.; Sellos, D.Y.; Zogaris, S.; Koblmueller, S. Lepadogaster purpurea (Actinopterygii: Gobiesociformes: Gobiesocidae) from the eastern Mediterranean Sea: Significantly extended distribution range. Acta Ichthyol. Piscat. 2017, 47, 417-421. [CrossRef]

72. Henriques, M.; Lourenço, R.; Almada, F.; Calado, G.; Gonçalves, D.; Guillemaud, T.; Cancela, M.L.; Almada, V.C. A revision of the status of Lepadogaster lepadogaster (Teleostei: Gobiesocidae): Sympatric subspecies or a long misunderstood blend of species? Biol. J. Linn. Soc. 2002, 76, 327-338. [CrossRef]

73. Almada, F.; Henriques, M.; Levy, A.; Pereira, A.; Robalo, J.; Almada, V.C. Reclassification of Lepadogaster candollei based on molecular and meristic evidence with a redefinition of the genus Lepadogaster. Mol. Phylogenet. Evol. 2008, 46, 1151-1156. [CrossRef]

74. Francour, P.; Goren, M.; Bilecenoglu, M.; Tunesi, L. Lepadogaster lepadogaster. The IUCN Red List of Threatened Species 2011: E.T194812A9140987. Available online: https://www.iucnredlist.org/species/194812/9140987 (accessed on 4 May 2021).

75. Karpova, E.; Boltachev, A.; Statkevich, S.; Danylyuk, O.; Turbanov, I. Cryptobenthic fauna of the mussel farm's collectors. Turk. J. Fish. Aquat. Sci. 2015, 15, 505-515. [CrossRef]

76. Galil, B.; Goren, M. Rosh-Hanikra Grottoes, Israel-A refuge for the critically endangered and for opportunistic invasives. In Marine Caves of the Eastern Mediterranean Sea. Biodiversity, Threats and Conservation; Öztürk, B., Ed.; Publication 53; Turkish Marine Research Foundation (TUDAV): Istanbul, Turkey, 2019; pp. 159-165.

77. Bori, C.; Gili, J.M.; Garcìa, A. Presencia de Oligopus ater Risso, 1810 (Pisces, Ophidiiformes) en cuevas submarinas del litoral NE de Mallorca. Miscellània Zool. 1985, 9, 401-404.

78. Tortonese, E. Distribution and ecology of endemic elements in the Mediterranean fauna (fishes and echinoderms). In Mediterranean Marine Ecosystems; Springer: Boston, MA, USA, 1985; pp. 57-83. 
79. Louisy, P. Guide d'Identification des Poissons Marins: Europe de l'Ouest et Méditerranée; Editions Eugen Ulmer: Paris, France, 2002; pp. $1-430$.

80. Zander, V.C.D.; Heymer, A. Morphologische and ökologische Untersuchungen an den speleophilen Schleimfischartigen Tripterygion melanurus Guichenot, 1850 und T. minor Kolombatovic, 1892 (Perciformes, Blennioidei, Tripterygiidae). J. Zool. Syst. Evol. Res. 1976, 14, 41-59. [CrossRef]

81. Katsanevakis, S.; Coll, M.; Piroddi, C.; Steenbeek, J.; Lasram, F.B.R.; Zenetos, A.; Cardoso, A.C. Invading the Mediterranean Sea: Biodiversity patterns shaped by human activities. Front. Mar. Sci. 2014, 1, 1-11. [CrossRef]

82. Gerovasileiou, V.; Voultsiadou, E.; Issaris, Y.; Zenetos, A. Alien biodiversity in Mediterranean marine caves. Mar. Ecol. 2016, 37, 239-256. [CrossRef]

83. Rilov, G. Multi-species collapses at the warm edge of a warming sea. Sci. Rep. 2016, 6, 1-14. [CrossRef]

84. Edelist, D.; Rilov, G.; Golani, D.; Carlton, J.T.; Spanier, E. Restructuring the Sea: Profound shifts in the world's most invaded marine ecosystem. Divers. Distrib. 2013, 19, 69-77. [CrossRef]

85. Rilov, G.; Peleg, O.; Yeruham, E.; Garval, T.; Vichik, A.; Raveh, O. Alien turf: Overfishing, overgrazing and invader domination in south-eastern Levant reef ecosystems. Aquat. Conserv. Mar. Freshw. Ecosyst. 2018, 28, 351-369. [CrossRef]

86. Micheli, F.; Halpern, B.S.; Walbridge, S.; Ciriaco, S.; Ferretti, F.; Fraschetti, S.; Lewison, R.; Nykjaer, L.; Rosenberg, A.A. Cumulative human impacts on Mediterranean and Black Sea marine ecosystems: Assessing current pressures and opportunities. PLoS ONE 2013, 8, e79889. [CrossRef]

87. Giakoumi, S.; Sini, M.; Gerovasileiou, V.; Mazor, T.; Beher, J.; Possingham, H.P.; Abdulla, A.; Çinar, M.E.; Dendrinos, P.; Gucu, A.C.; et al. Ecoregion-based conservation planning in the Mediterranean: Dealing with large-scale heterogeneity. PLoS ONE 2013, 8, e76449. [CrossRef]

88. Markantonatou, V.; Giakoumi, S.; Koukourouvli, N.; Maina, I.; Gonzalez-Mirelis, G.; Sini, M.; Maistrelis, K.; Stithou, M.; Gadolou, E.; Petza, D.; et al. Marine spatial plans focusing on biodiversity conservation: The case of the Aegean Sea. Conserv. Mar. Freshw. Ecosyst. in press. 